\title{
DESIGN OF MAXIMUM POWER POINT TRACKER CONTROLLER FOR BOOST CONVERTER PHOTOVOLTAIC ARRAY SYSTEM BASED ON FUZZY MAMDANI LOGIC
}

\author{
*Jaaffar J.Duair ${ }^{1}$
}

\author{
Ammar I. Majeed ${ }^{1}$
}

Ghusoon M. Ali ${ }^{1}$

1) Electrical Engineering Department, College of Engineering, Mustansiriyah University, Baghdad, Iraq

\begin{abstract}
This paper discusses the analysis for a proposed design of a maximum power point tracker (MPPT) controller for a photovoltaic (PV) array solar system. Deploying a fuzzy Mamdani logic to track the maximum- power for the PV system when the atmospheric conditions are changed. The fuzzy Mamdani logic controller techniques have high efficiency, rapid response to new environmental factors, and are unaffected by circuit parameter changes. This controller able to adjust the duty cycle fed switching circuit of $D C / D C$ boost to increase the output voltage of the system. By using a Simulink MATLAB, the system with the controller is stimulated and studied for different atmospheric conditions. We choose three irradiation levels of 1000,800 , and $600 \mathrm{~W} / \mathrm{m}^{2}$ at a certain temperature of $25{ }^{\circ} \mathrm{C}$ and three values for the temperature of $20,30,35{ }^{\circ} \mathrm{C}$ at irradiation level of 1000 $\mathrm{W} / \mathrm{m}^{2}$ to calculate the efficiency of the algorithm. The extracted efficiency results are compared with the usual Perturb and Observe algorithm MPPT topology (P\&O) for the same system design and atmospheric conditions. It was found to be the controller efficiency of the proposed algorithm is improved up to $99 \%$. This improvement maximizes performance and reduces costs, provides adequate current and voltage, and minimizes booster losses, and improves booster reliability.
\end{abstract}

Keywords: MPPT, fuzzy, Mamdani, boost converter, photovoltaic, microgrid.

\section{Introduction}

Solar energy is the crucial energy source for all life systems. It is a renewable, inexhaustible, clean, vast, free, and environmentally friendly energy source. The conversion of the energy from solar to electrical is a common renewable energy source [1]. The commercial solar system consists of different parts, such as solar panels, inverters, batteries, controllers, and other supported components. These parts' efficiencies are contributed to the total efficiency. In this regard, the inverter efficiency is essential that indicates how much DC is inverted to AC power [2]. The efficiency of the solar system can be elevated by improving the design and topology of the booster or inverter using the MPPT algorithm [1].

MPPT tracking technology is very important in solar PV array systems because the solar panel has non-linear I-V characteristics. It has one maximum point power for a specific parameter (irradiation and temperature)[1]. This point is affected by the geographic spot of the solar panel, the season of the year, weather conditions, the presence of clouds, and the different times of the day. All these factors can be summarized by the two main factors, irradiation and temperature[2]. There are several popular MPPT methods previously reported;

\footnotetext{
*Corresponding Author: engjjd@gmail.com
} 
these methods vary according to their difficulty, algorithmic used, accuracy, time response, price, and technical topology [3].

In this article, the FMLC-based MPPT algorithm was suggested to drive the DC/DC boost converter for the solar PV array simulated Simulink MATLAB. The simulation results are shown the preference and reliability of the system as compared with the traditional P\&O algorithm.

\section{Topology and Characteristics of PV Array System.}

The main parts of the suggested PV array system are; photoelectric cells panel array, boost converter, and MPPT fuzzy controller, the system block diagram as shown in Fig. 1.

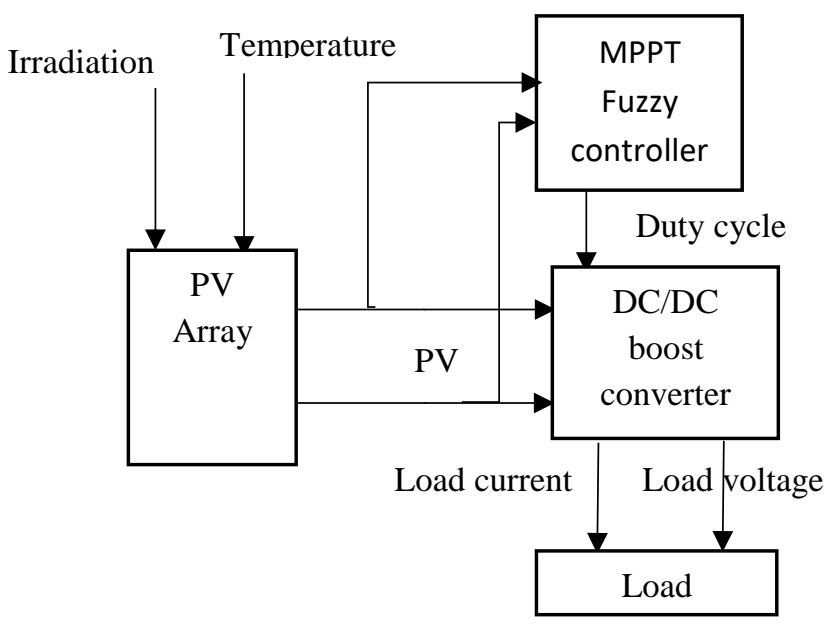

Figure 1. PV array system block diagram

\subsection{Photovoltaic array (PV solar array)}

PV array is consists of a group of photovoltaic cells. A PV cell is a light-sensitive semiconductor $\mathrm{p}-\mathrm{n}$ junction device. The $\mathrm{p}-\mathrm{n}$ cell is fabricated from a thin semiconductors wafer. There are two types of materials that photovoltaic cells are often made from Monocrystalline Silicon and Polycrystalline Silicon [7]. These devices convert solar energy into electrical energy, each panel consist of a set of photovoltaic cell and a group of them will be
PV array. The voltage and current that come out of this panel can feed simple loads such as motors and light directly, but most systems need voltage regulators, which can be a boostconverter, a back-converter, or a back-boost converter [6]. The converter needs an MPPT controller to make the most benefit of solar panels.

The PV cell is connected in series and shunt combinations to form a solar PV array panel, and every PV cell generates around $0.5 \mathrm{~V}$ (for Silicon). The voltage extracted from a PV cell is mainly based on the cell design and materials, while the current be governed mainly by the absorbed solar light and the cell size area. The equivalent circuit for a PV cell consists of a current source with a shunt diode. There are losses related to the PV cell operation or solar cell resistors. The series and parallel resistors represent the voltage drop at both ends of the PV cell.

The PV panel's model may be presented by the equations below[4].

$$
\begin{aligned}
& I_{o p}=I_{p v}-I_{s}\left(\exp \frac{q\left(V_{o p}+R_{s e} I_{o p}\right)}{a K T N_{s}}-1\right)- \\
& \frac{\left(V_{o p}+I_{o p} R_{s e}\right)}{R_{p a}} \\
& I_{p v}=\left(I_{s c}+K_{i}(T-298.15)\right) \frac{G}{1000} \\
& I_{s}=\frac{I_{s c}+K_{i}(T-298.15)}{\exp \left(q\left(\left(V_{o c}+K_{v}(T-298.15) / a K T N_{s}\right)\right)^{-1}\right.}
\end{aligned}
$$

\section{Where :}

$\mathrm{I}_{\mathrm{op}}$ : output current, $\mathrm{I}_{\mathrm{pv}}$ : photovoltaic cell current, $\mathrm{I}_{\mathrm{s}}$ : saturation current, q: charge of the electron, $\mathrm{V}_{\mathrm{op}}$ : output voltage, $\mathrm{R}_{\mathrm{se}}$ : series resistance, a: ideality factor of the diode, $\mathrm{K}$ : Boltzmann constant, $\mathrm{N}_{\mathrm{s}}$ : Number of connected cells in series, $\mathrm{R}_{\mathrm{pa}}$ : parallel shunt resistance, $\mathrm{K}_{\mathrm{i}}$ : temperature coefficient of short-circuit current, $\mathrm{K}_{\mathrm{v}}$ : is the temperature coefficient of open-circuit voltage, G: irradiation of sun $\mathrm{W} / \mathrm{m}^{2}$, $\mathrm{I}_{\mathrm{sc}}$ : short circuit current and $\mathrm{V}_{\mathrm{op}}$ : open-circuit voltage. 
Equations 1, 2 and 3, demonstrate that the productivity of the solar cells depends on the parallel and series resistance, temperature, and the amount of solar irradiation. The parallel and series resistance cannot be changed because it is related to the fabrication of the solar cell and panel. Hence, the productivity of the solar panel depends on the temperature and the amount of irradiation [8].

Here, the MATLAB Simulink is deployed to provide PV Module type Sunpower SPR-30-EWHT-D with specification at stander atmosphere condition STC, irradiation of 1000 $\mathrm{W} / \mathrm{m}^{2}, \mathrm{~T}=25^{\circ} \mathrm{C}$ as shown in Table 1 and Table 2.

Table 1. Array data of PV Module type Sunpower SPR-30-E-WHT-D

$$
\text { Parallel strings }
$$

Series-connected modules per

Cells per module Maximum power of $\mathrm{PV}$ array's maximum power

The voltage at maximum power point of PV array

Current at maximum power

Table 2. Module data of PV Module type Sunpower SPR-30-E-WHT-D

\begin{tabular}{cc}
\hline Typical electrical features & Value \\
\hline Maximum Power & $305.22 \mathrm{~W}$ \\
Cells per module (Ncell) & 96 \\
Open circuit voltage Voc & $64.2 \mathrm{~V}$ \\
Voltage at maximum power point & $54.7 \mathrm{~V}$ \\
Short-circuit current Isc & $5.69 \mathrm{~A}$ \\
Current at maximum power point & $5.58 \mathrm{~A}$ \\
Temperature coefficient of Voc & $-0.27269 \% /{ }^{\circ} \mathrm{C}$ \\
Temperature coefficient of Isc & $0.061745 \% /{ }^{\circ} \mathrm{C}$ \\
\hline
\end{tabular}

Figs. 2 (a) and (b) show the point of maximum power points at different levels of solar irradiance and temperature. Fig. 2 (a) shows that the maximum power can be obtained at $25^{\circ} \mathrm{C}$ when the irradiance is at the maximum value of $1000 \mathrm{~W} / \mathrm{m}^{2}$. While Fig. 2 (b) illustrates the maximum power points that can be achieved for $1000 \mathrm{~W} / \mathrm{m}^{2}$ irradiance when the temperature at a minimum studied the value of 1000
$\mathrm{W} / \mathrm{m}^{2}$. The power feature of a photovoltaic module indicates that the power is maximum depending on the amount of irradiation or temperature at a certain point on the curve.
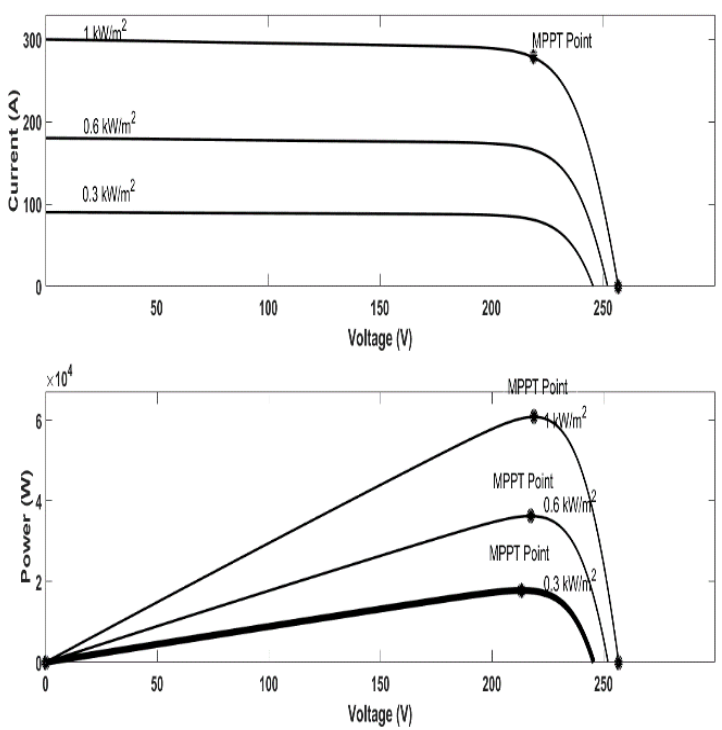

(a)
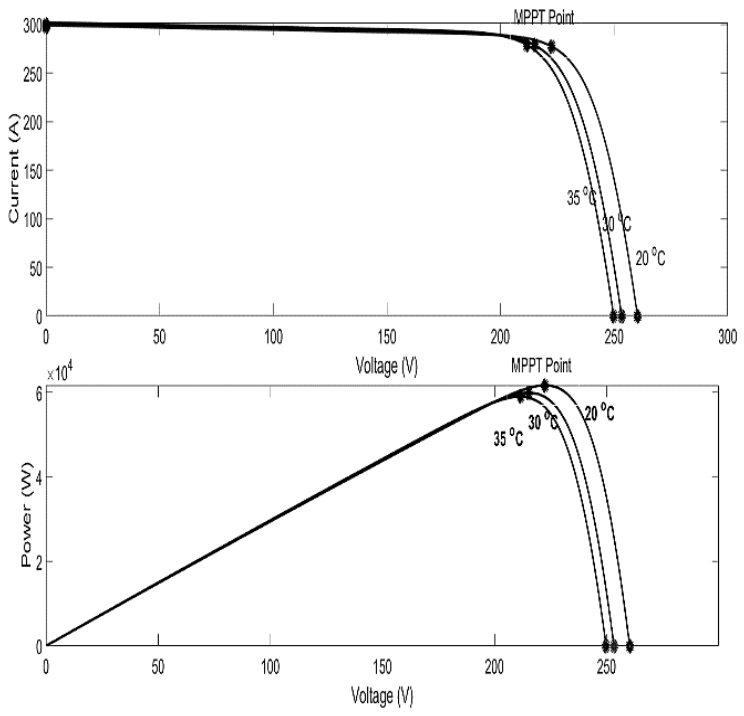

(b)

Figure 2. The power, and current versus voltage generated from this PV array (a) at a certain temperature $\left(\mathrm{T}=25^{\circ} \mathrm{C}\right)$ for irradiance of $1000,600,300 \mathrm{~W} / \mathrm{m}^{2},(\mathrm{~b})$ at certain irradiance of $1000 \mathrm{~W} / \mathrm{m}^{2}$ for different temperatures of $20,30,35^{\circ} \mathrm{C}$.

\subsection{DC / DC boost converter (chopper)}

To inject electrical energy from the solar system to the grid, it is necessary to have a converter, and according to the design of the system, it was 
a boost-converter, a back-converter, or a backboost converter [5]. The output of the converter feeds the bus circuit that feeds DC/AC inverter and battery controller for the PV array system. Fig. 3 shows the block diagram of the commonly used system of the microgrid.

The second stage of the solar energy system is the boost converter (chopper). The chopper is controlled by the maximum power point tracking MPPT to ensure the arrival of the greatest energy from the solar cell. This stage alters the energy produced from the photovoltaic cells due to the different weather conditions and hours of the day or even the passage of a bird in front of the solar panel.

The controller generates a duty cycle suitable for controlling the switching device of the boost converter using the technique of pulse width modulation (PWM). The type of transistor deployed in the circuit is chosen based on the level of the system's power. For small power, BJT is used, for medium power, MOSFET is utilized, and for high power, using IGBT. Here the IGBT is used. The storage device in the booster is capacitors and inductors, and the power source is a DC source such as a PV array [6].

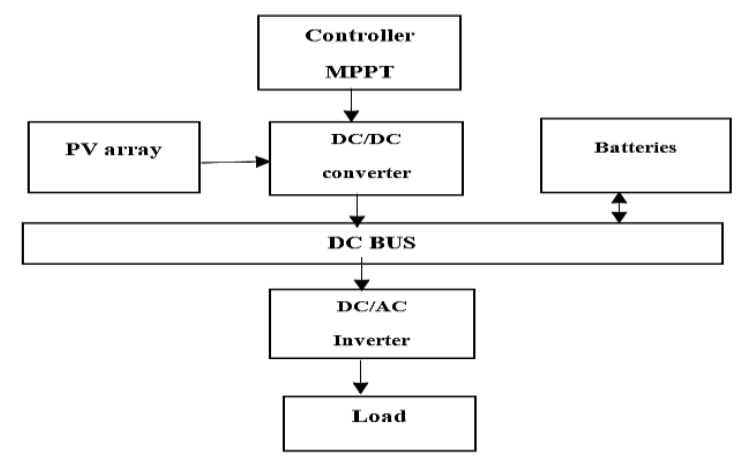

Figure 3 . Solar PV array system block diagram with $\mathrm{DC} / \mathrm{AC}$ inverter and storage batteries.

Fig. 4 shows the DC/DC boost converter works briefly describe by opening and closing an electronic switch. It is a DC/DC boost converter. The output voltage is greater than the input voltage [6].

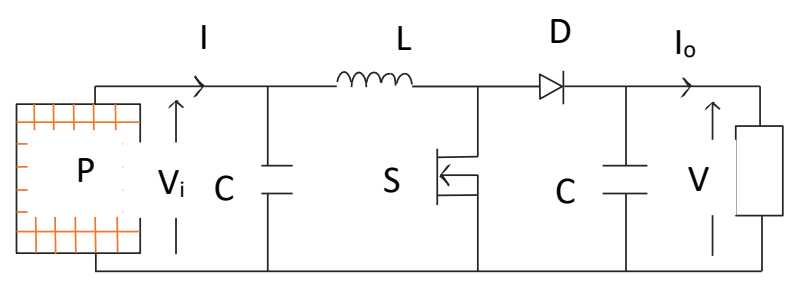

Figure 4. Schematic diagram of a DC-DC chopper boost converter circuit $[10]$.

It is regarded as the crucial element of a solar energy PV array system. It controls the process of tracking power and controlling the duty cycle control over the voltage raising in the step-up converter. Depending on the form of the algorithm, the tracking response varies in time, accuracy, and efficiency [7]. Most of the designs are based on constant output. Even the voltage pulsation in the input has existed. The challenge of the MPPT model is that the output voltage and input voltage are different[8]. Because of the nonlinearity of $\mathrm{I}-\mathrm{V}$ characteristics of photovoltaic energy[9], therefore the MPPT technique is used to operate the PV array at maximum efficiency to produce the maximum output power. Fig. 3 (a) illustrates that the current-voltage curve has nonlinearity characteristics and has one maximum power point.

MPPT methods differ in complexity, sensor specifications, speed of convergence, cost, performance range, design of hardware, popularity, and other aspects[10].

Fig. 5 illustrates the characteristic of the proposed solar PV array's power curve for a temperature of $25^{\circ} \mathrm{C}$ and a radiation level of $1000 \mathrm{~W} / \mathrm{m}^{2}$. Considering the MPPT to find the voltage maximum power point (VMPP) or the current maximum power point (IMPP) 
automatically at which the PV array can run. In order to achieve the optimum PMPP output at a specified temperature and irradiance.
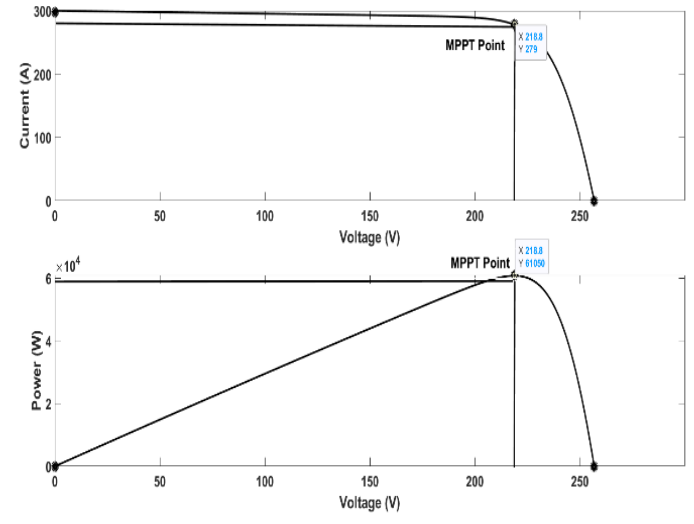

Figure 5. The characteristic of proposed power solar photovoltaic array curve.

Fig. 5 demonstrates the maximum amount of current is $298 \mathrm{~A}$, at zero voltage applied (ISC). At the same atmospheric conditions, the maximum amount of voltage is $256 \mathrm{~V}$ at zero current ( $\mathrm{V}_{\mathrm{OC}}$ ). These points cannot be considered as the maximum level of power points MPPT.

The importance of the MPPT's algorithms is notable for the maximum current and voltage product to give the maxim power $(\mathrm{P}=\mathrm{VI})$. They were noting that for any atmospheric modification, the current and voltage will change. Accordingly, the algorithm will change from the maximum power point to the new value. The main flow chart for the proposed MPPT algorithm illustrates in Fig. 6.

Fig. 6 shows the topology of MPPT using the Fuzzy Mamdani logic controller. The system has obtained the voltage and current of the PV array at a certain time, product them to get power, and compare the result with the previous result. When the current result is greater than the previous result, the system will decrease the PWM time, and if the current result is less than the previous result, the system will increase the PWM time.

Different algorithm strategies were suggested for MPPT, such as the Perturb and Observe (P\&O) method, the incremental-conductance (IncCond) strategy, neural networks, and Fuzzy logic system controllers[11].

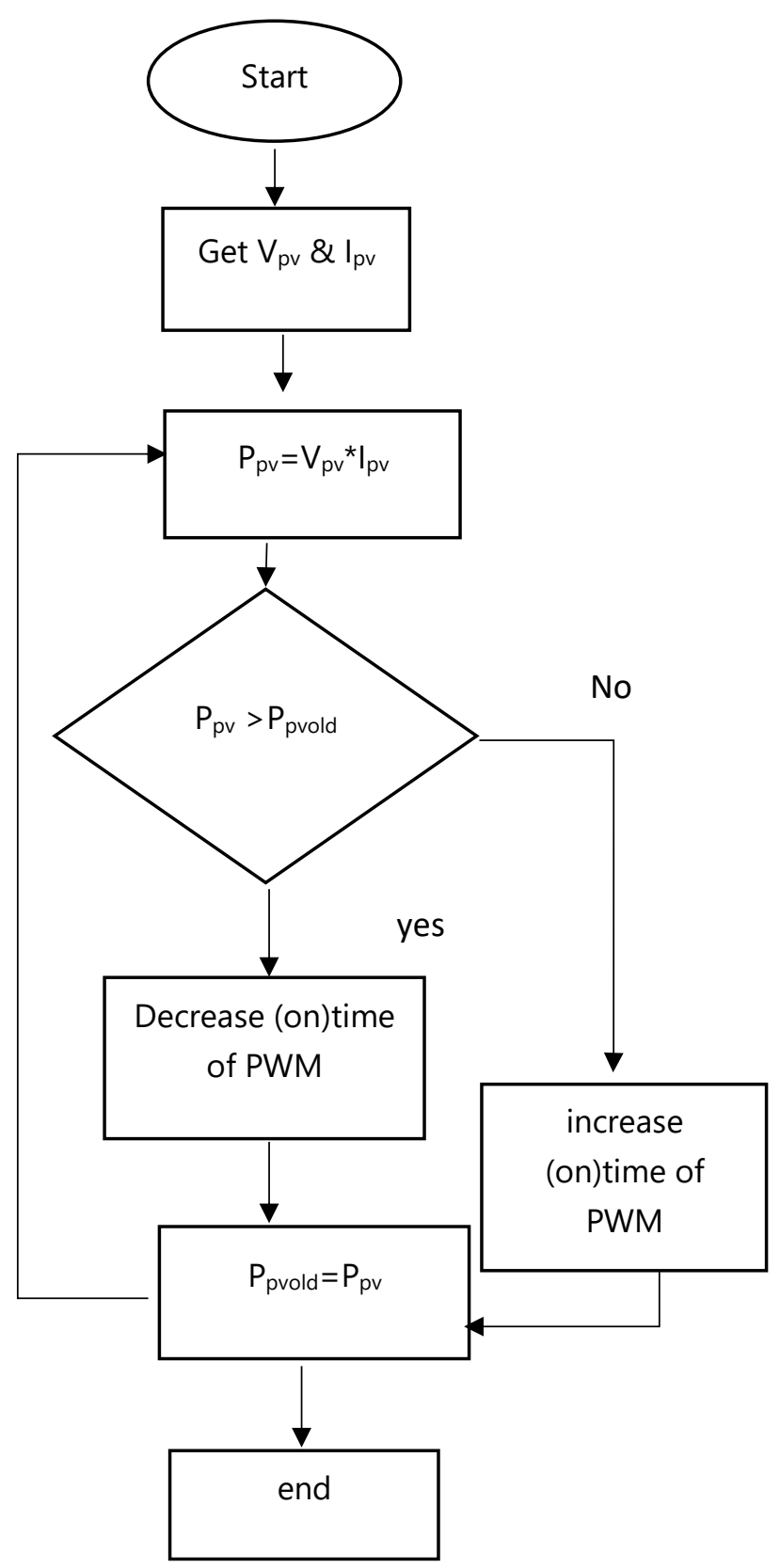

Figure 6. The main flow chart of MPPT 


\subsection{Fuzzy Mamdani logic-based MPPT controller}

There are two types of the fuzzy logic controller using in MPPT controller, the Takagi-Sugeno Fuzzy logic controller (FLC) and the Fuzzy Mamdani logic controller based on fuzzy interface system (FIS)[12]

MPPT using Fuzzy Mamdani Logic Control has many benefits of increased efficiency and high performance and simple design. Additionally, the exact system model is not needed for this technique. This system contains three simple stages fuzzification, Fuzzy rule, inference engine, and defuzzification [13] as shown in Fig. 7.

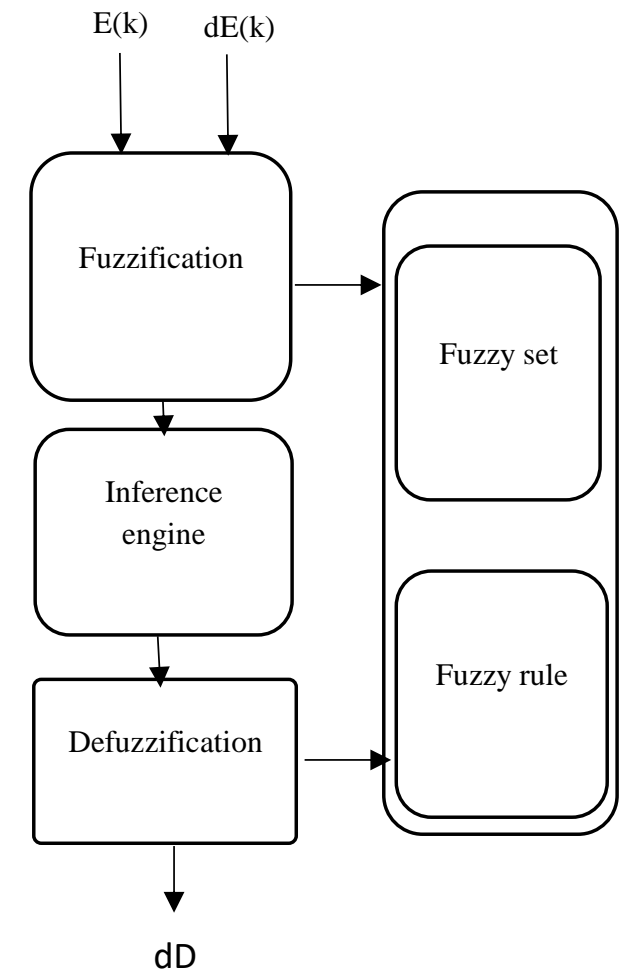

Figure 7 .Topology of MPPT using Fuzzy Mamdani Logic Controller

\subsubsection{Fuzzification}

The linguistic variables are given membership feature values by seven subsets of fuzzy subsets. The seven subsets are negative big (NB), negative medium (NM), negative small
(NS), zero (ZE), positive small (PS), positive medium (PM), and positive big (PB). The division of fuzzy subsets and the membership function form are to confirm the form to the appropriate system.

Fig.8 shows the input error (E) and error change (CE) values are normalized by the scaling factor of input. The scaling factor for the input has been developed in this methodology so that input values range from -1 to +1 .

The proposed framework in this paper has two input variables: $\mathrm{E}$ and $\mathrm{CE}$, as well as one for output change of duty cycle $(\Delta \mathrm{D})$ [19]. If the value of $(\Delta D)$ is positive, meaning increase pulse width, and if $(\Delta D)$ is negative, indicate a decrease of the pulse width of PWM.

Fuzzification is the process of converting crisp numerical inputs into linguistic variables depending on the degree to which they belong to specific sets. Each linguistic phrase is assigned a grade using membership functions[14]. sampled times $\mathrm{k}$ are defined as follows:

$$
\begin{aligned}
& E(\mathrm{~K})=\frac{\mathrm{P}(\mathrm{K})-\mathrm{P}(\mathrm{K}-1)}{\mathrm{V}(\mathrm{K})-\mathrm{V}(\mathrm{K}-1)} \\
& \mathrm{CE}(\mathrm{K})=\mathrm{E}(K)-\mathrm{E}(K-1) \\
& \Delta \mathrm{D}=\mathrm{D}(K)-\mathrm{D}(\mathrm{K}-1)
\end{aligned}
$$

Here $\mathrm{K}$ current (instantons) value, (K-1) previous value, $\mathrm{P}(\mathrm{k})$, and $\mathrm{V}(\mathrm{k})$ are the solar module's immediate power and voltage, respectively.

The linguistic variables allocated to $\triangle \mathrm{D}$ for various combinations of $\mathrm{E}(\mathrm{K})$ and $\mathrm{CE}(\mathrm{K})$ are determined by the power converter utilized.

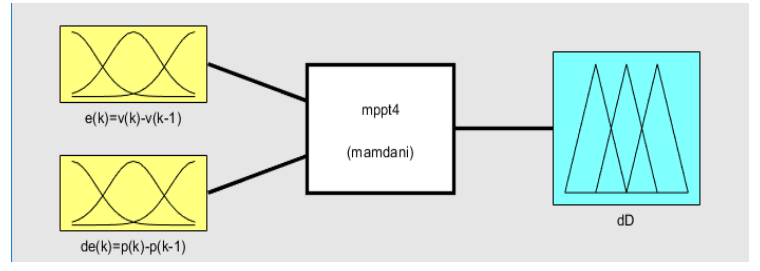

(a) 


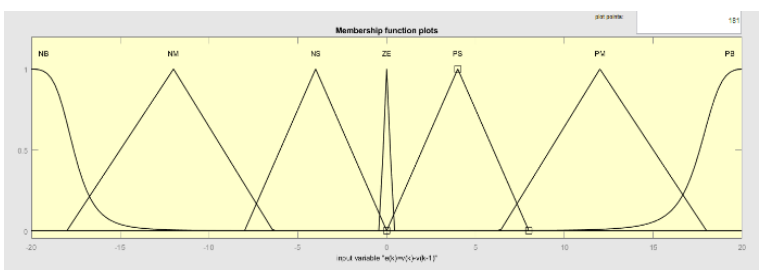

(b)

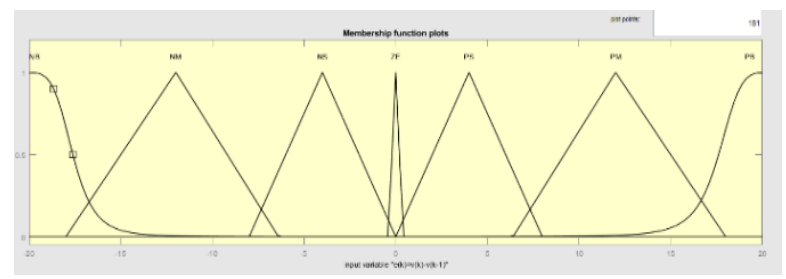

(c)

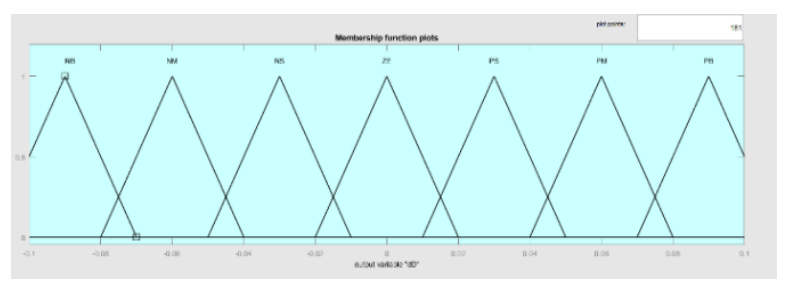

(d)

Figure 8. Fuzzy logic Mamdani membership functions for inputs and output variables; (a) Fuzzy Mamdani design, (b) Input of variable "error", (c) Input of variable "error change", and (d) Output of variable "duty cycle".

This arrangement's triangular form of the membership presumes that there is only one dominant for every unique input Subset fuzzy. Seven subsets for (E), (CE), and (D) output is deployed to increase the accuracy for this topology; they are some previously reported work [15], [16] that have utilized five subsets only.

\subsubsection{Inference Engine}

The inference engine is the composition operation by which the performance of the control can be created. The composition MAXMIN method was proposed in the fuzzy toolbox in MATLAB. The output membership function of each rule is provided by the minimum (MIN) operator and maximum (MAX). Mamdani's inference method is used here [17]. It is the combination of fuzzy Max-Min.

Forty-nine rules based on seven sub-sets are used. The introduction of forty-nine rules is a very time-bound consumption. However, It has a greater accuracy and dynamic response time.

\subsubsection{Defuzzification}

The defuzzification with this system is the center of gravity (COG). The duty cycle is represented by the FLC production. The COG system is simple and quick to use. The defuzzification of the COG process of a system of rules developed by:

$\Delta D=\frac{\sum_{a=1}^{k} \mu\left(D_{a}\right)-D_{a}}{\sum_{a=1}^{k} \mu\left(D_{a}\right)}$

The FLC output is used to adjust PWM ( by increasing pule width or decreasing it ) to control the generated pulse for IGBT switching in the DC-DC boost converter. Table 2 summarizes the Fuzzy Mamdani logic controller rule.Table contain 49 rule subset of crisp.

Table 3 Fuzzy Logic Controller Rule Table.

\begin{tabular}{clllllll}
\hline CE(K) & \multicolumn{9}{c}{ E(k) } \\
\cline { 2 - 7 } & NB & NM & NS & ZE & PS & PM & PB \\
\hline NB & NB & NB & NB & NM & NM & NS & ZE \\
NM & NB & NB & NM & NM & NS & ZE & PS \\
NS & NB & NM & NM & NS & ZE & PS & PM \\
ZE & NM & NM & NS & ZE & PS & PM & PM \\
PS & NM & NS & ZE & PS & PM & PM & PB \\
PM & NS & ZE & PS & PM & PM & PB & PB \\
PB & ZE & PS & PM & PM & PB & PB & PB \\
\hline
\end{tabular}

\section{Simulation and Result Aid MATLAB/SIMULINK.}

Fig. 9 depicts the simulation layout of the PV array solar model system with the aid of MATLAB/SIMULINK. It is constructed of a PV array, a DC/DC boost converter chopper, and an MPPT fuzzy controller connected to a booster switch device. In the simulation, the PV solar module type Sunpower SPR-30-E-WHT- 
$\mathrm{D}$, the characteristic and specification of the PV panel module is shown in Tables 1 and 2. The PV solar array with a $61050 \mathrm{~W}$ capacity consists of 4 series and 50 in parallel string connected PV solar modules.

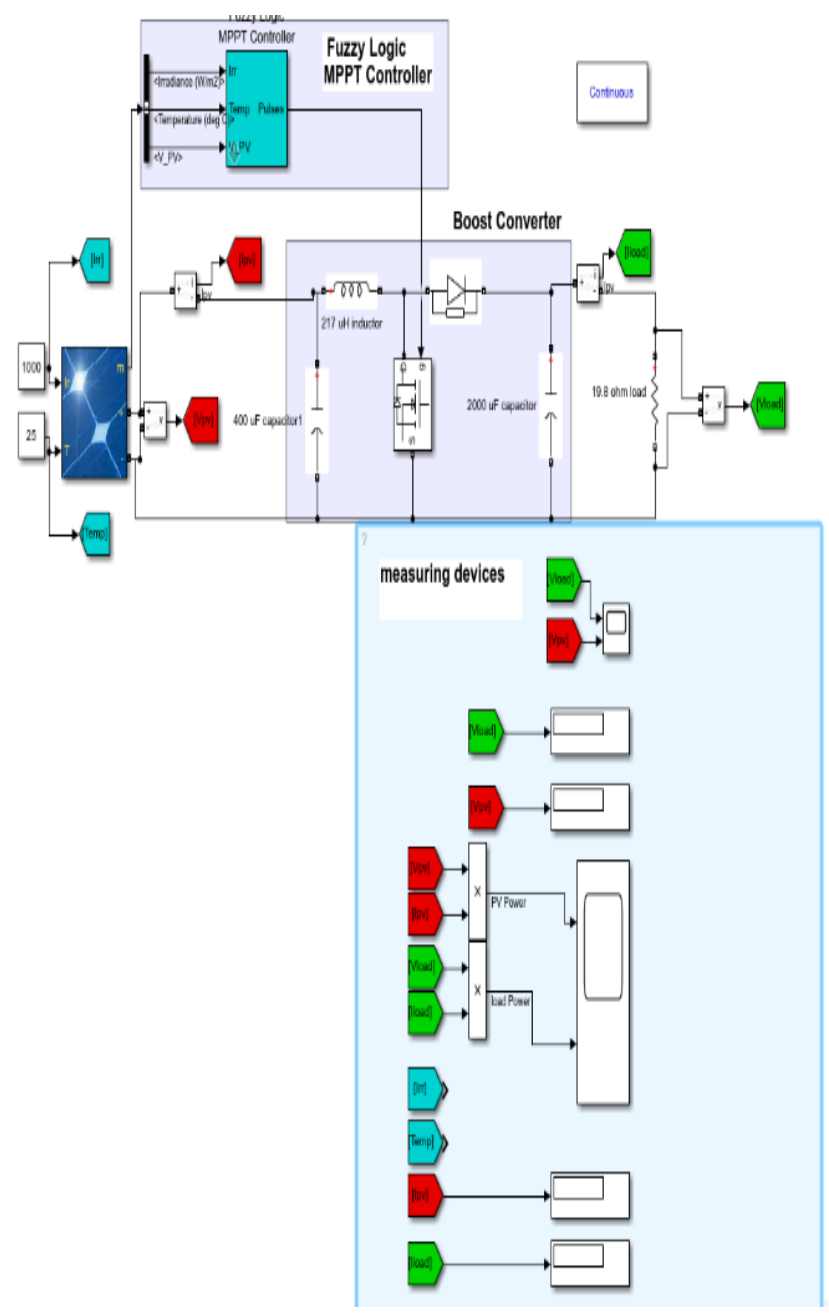

Figure 9. PV array solar model system DC to DC boost converter with fuzzy Mamdani MPPT controller

A DC/DC boost converter converts the input DC voltage $(218.8 \mathrm{~V})$ to the output DC voltage $(480 \mathrm{~V})$. The boost converter parameter in table 3.
Table 3. Boost converter parameter

\begin{tabular}{lc}
\hline Inductance & $718 \mu \mathrm{H}$ \\
Input capacitor & $400 \mu \mathrm{F}$ \\
Output & $2400 \mu \mathrm{F}$ \\
capacitor & \\
Frequency & $5000 \mathrm{HZ}$ \\
\hline
\end{tabular}

The fuzzy logic toolbox of Simulink is used to Implement the FMLC is simulated and compared result with the same system but using P\&O (Perturb and observe) MPPT controller from MathWorks site [18]as shown in Fig.10. Because of its simplicity, the traditional Perturb and Observe algorithm has been widely used. The MPP is the point at which the operating point and the operational point intersect. After a time of continuous observation and perturbation. The algorithm calculates the time to reach MPP by comparing the voltages and power of the period $(\mathrm{K})$ with the sample at a period $(\mathrm{K}-1)$.

If the power difference is positive, a minor voltage perturbation increases the power of the solar panel, and the voltage perturbation continues in the same direction. However, if delta power is negative, and the perturbation must be reduced to reach it [19].

The systems in Figs. 9 and 10 consist of a PV module, boost converter circuit, MPPT controller module, and measurement instruments (voltmeter, ammeter, and oscilloscope) to show the result of the simulation. The current and voltage values produced by the solar panels feed the boost converter circuit, and also these values will go to the MPPT controller to track the change in these values and produce an appropriate pulse to control the closing and opening of the switching circuit to make the most of the solar panels producing capacity. 


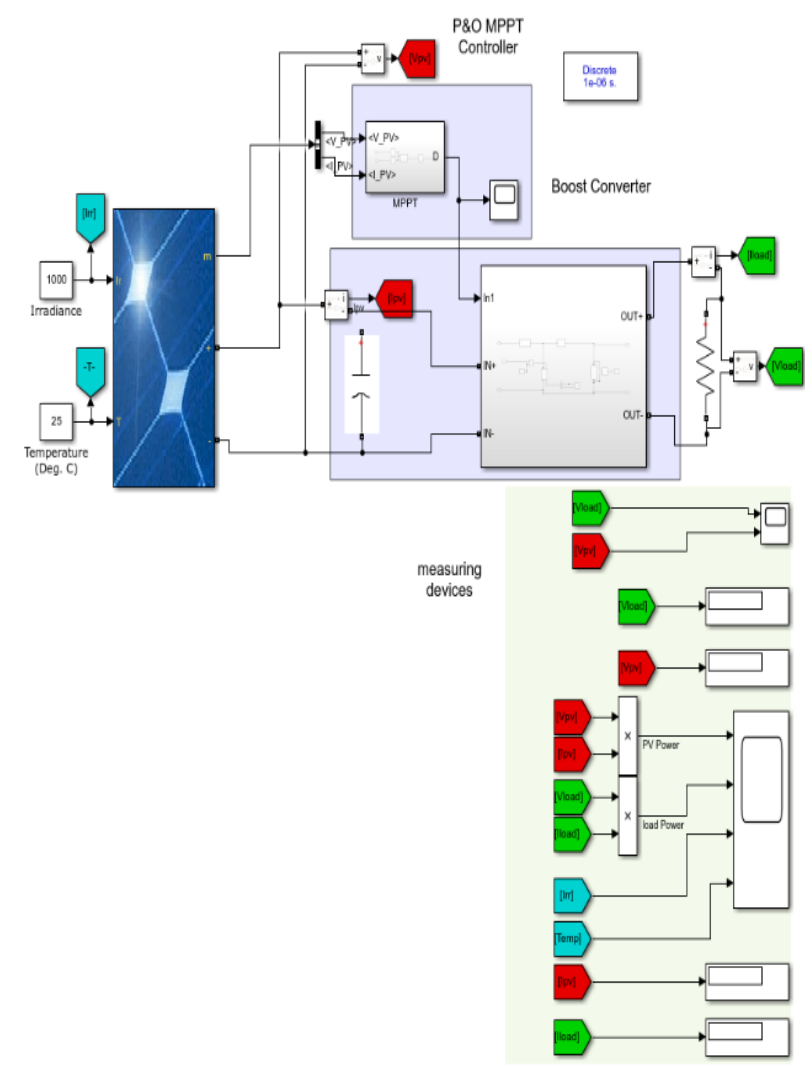

Figure 10. $\mathrm{PV}$ array solar model system with boost converter for DC to DC with P\&O MPPT controller.

Table 4 (a) presents the fuzzy Mamdani simulation result of input, the output power of the PV array system, and the calculated efficiency at the temperature of $25{ }^{\circ} \mathrm{C}$ and different irradiation levels of 1000,800 , and 600 $\mathrm{W} / \mathrm{m}^{2}$. Tables 4 (b) show the results under the same conditions for the P\&O method. Tables 4(a) and (b) is presented results to compare two MPPT topologies for power and efficiency. This indicates the fuzzy Mamdani topology has better efficiency at certain temperature multi irradiation than the $\mathrm{P} \& \mathrm{O}$ method.

Table 4. (a) Fuzzy MPPT power and efficiency at specific temperature multi irradiation.

\begin{tabular}{cccc}
$\begin{array}{c}\text { Irradiation } \\
\mathbf{W} / \mathbf{m}^{2} \text { at } \\
\left(\mathbf{2 5}^{\circ} \mathbf{C}\right)\end{array}$ & Pi (W) & Pop $(\mathbf{W})$ & $\begin{array}{c}\text { Efficiency } \\
\mathbf{P o p}_{\mathbf{p}} / \mathbf{P i n}_{\text {in }}\end{array}$ \\
\hline 1000 & 60483.15 & 60147.56 & 0.9944 \\
800 & 43747.6 & 43274.4 & 0.989
\end{tabular}

600

$19947.9 \quad 19855.6$

0.9953

The next table for P\&O power and efficiency at specific temperature multi irradiation.

Table 4. (b) $\mathrm{P} \& \mathrm{O}$ power and efficiency at specific temperature multi irradiation.

\begin{tabular}{cccc}
\hline $\begin{array}{c}\text { Irradiation } \\
\mathbf{W} / \mathbf{m}^{\mathbf{2}}\left(\mathbf{2 5}^{\circ} \mathbf{C}\right)\end{array}$ & $\mathbf{P i}(\mathbf{W})$ & Pop $(\mathbf{W})$ & $\begin{array}{c}\text { Efficiency } \\
\mathbf{P}_{\text {op }} / \mathbf{P}_{\text {in }}\end{array}$ \\
\hline 1000 & 60840.64 & 55756.8 & 0.916 \\
800 & 48355.11 & 45169.6 & 0.934 \\
600 & 34792.8 & 34527.136 & 0.992 \\
\hline
\end{tabular}

Table 5. (a ) Fuzzy MPPT power and efficiency at specific irradiation multi temperature

\begin{tabular}{cccc}
\hline $\begin{array}{c}\text { Temperature } \\
\mathbf{C}^{\circ} \text { at } \\
\text { irradiation } \\
(\mathbf{1 0 0 0}) \mathbf{W} / \mathbf{m}^{2}\end{array}$ & Pi $(\mathbf{W})$ & Pop $(\mathbf{W})$ & $\begin{array}{c}\text { Efficiency } \\
\mathbf{P}_{\text {op }} / \mathbf{P}_{\text {in }}\end{array}$ \\
\hline 20 & 61687.9 & 61318.14 & 0.994 \\
30 & 59590.36 & 59231.39 & 0.9939 \\
35 & 58492.45 & 58044.85 & 0.9923 \\
\hline
\end{tabular}

Table 5. (b) P\&O power and efficiency at specific irradiation multi temperature

\begin{tabular}{cccc}
\hline $\begin{array}{c}\text { Temperature } \\
\mathbf{C}^{\circ} \text { at } \\
\text { irradiation } \\
(\mathbf{1 0 0 0}) \mathbf{W} / \mathbf{m}^{2}\end{array}$ & Pi $(\mathbf{W})$ & Pop $(\mathbf{W})$ & $\begin{array}{c}\text { Efficiency } \\
\mathbf{P}_{\text {op }} / \mathbf{P}_{\text {in }}\end{array}$ \\
\hline 20 & 61709.9 & 56705.6 & 0.918 \\
30 & 57811 & 54303.12 & 0.939 \\
35 & 57128.84 & 52801.32 & 0.924 \\
\hline
\end{tabular}

Tables 5 (a) and (b) present the same information at constant solar irradiation at $1000 \mathrm{~W} / \mathrm{m}^{2}$ for different temperatures values 20 , $30,35^{\circ} \mathrm{C}$, also result and comparison of MPPT topology for power and efficiency at certain irradiation multi-level of temperature.

This simulation result from Tables 3 and 4 indicates that the effeminacy of FMLC greater and better than of $\mathrm{P} \& \mathrm{O}$ algorithm in the other wordless losses in the energy for FMLC than $\mathrm{P} \& \mathrm{O}$. the output power of $\mathrm{P} \& \mathrm{O}$ tecnick unstable 
and fluctuating because of The principle of this controller is to provoke perturbation by acting (decrease or increase) on the PWM duty cycle and observing the effect on the output PV power.
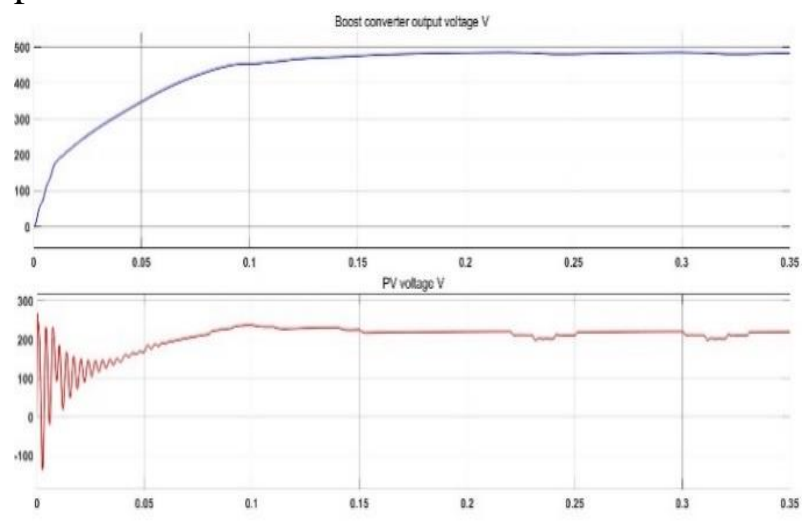

(a)
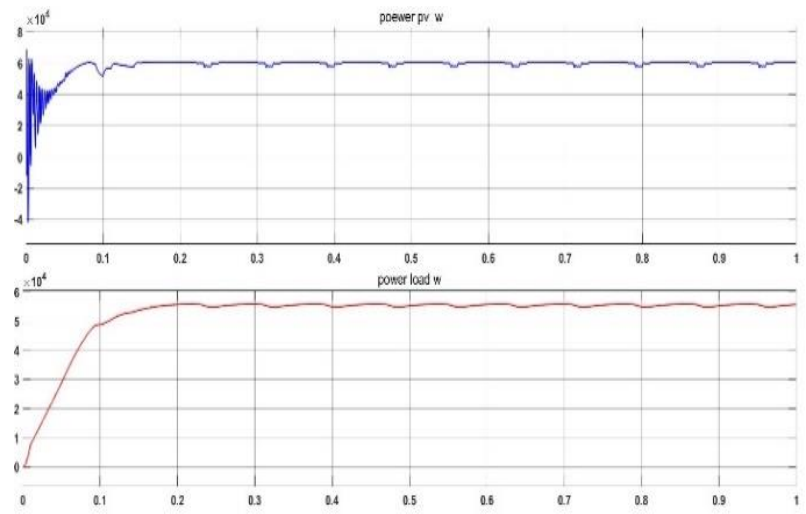

(b)

Figure 11. (a) the boost converter input and output voltage (b) power for PV array and output of booster based on P\&O topology of MPPT in certain temperature $25^{\circ} \mathrm{C}$ and certain irradiance $1000 \mathrm{~W} / \mathrm{m}^{2}$

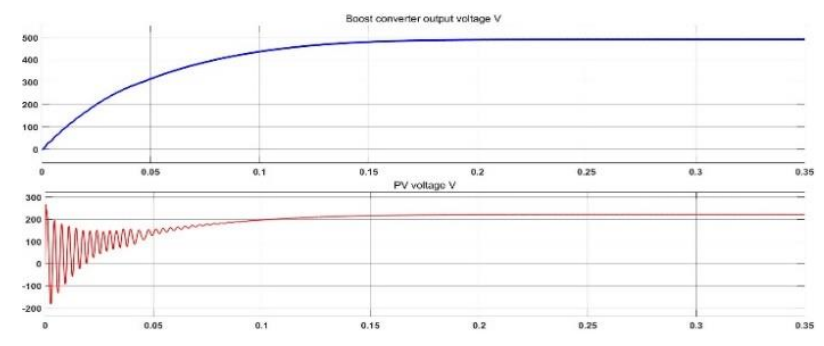

(a)

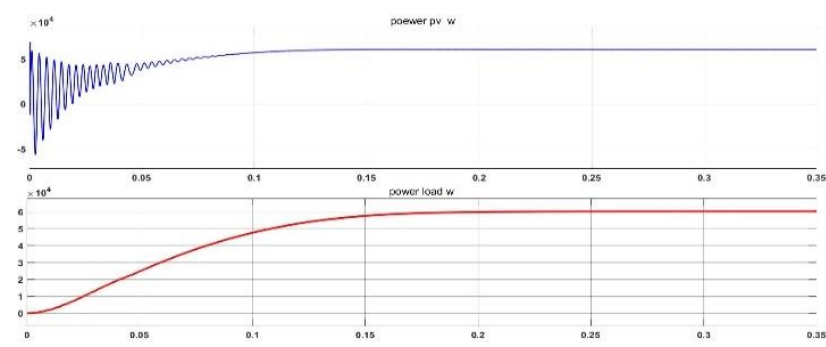

(b)

Figure 12. (a) the boost converter input and output voltage (b) power for PV array and output of booster based on fuzzy Mamdani topology of MPPT in certain temperature $25^{\circ} \mathrm{C}$ and certain irradiance $1000 \mathrm{~W} / \mathrm{m}^{2}$

The previous Figs. 11 and 12 show the output of boost converter for stander test condition STC atmosphere, and clear that the output of booster for $\mathrm{P} \& \mathrm{O}$ algorithm not only less efficient than FMLC algorithm but there are fluctuating in the output voltage and power curve. However, in FMLC MPPT, after setting time, the voltage and power output curve reaching a smooth, stable curve that means that the power in $\mathrm{P} \& \mathrm{O}$ is unstable in a certain condition.

Now let's compare the results that we got from our study with a previous study by another researcher. The researcher[20] used five subsets in his research, results showing over different temperatures and different solar radiation. The results are in table 6 (a)and (b).

Table 6. (a) Fuzzy MPPT efficiency at specific temperature multi irradiation for two studies

\begin{tabular}{ccc}
$\begin{array}{c}\text { Irradiation } \\
\mathbf{W} / \mathbf{m}^{\mathbf{2}} \text { at } \\
\left(\mathbf{2 5}^{\circ} \mathbf{C}\right)\end{array}$ & $\begin{array}{c}\text { Efficiency } \\
\mathbf{P}_{\text {op }} / \mathbf{P}_{\text {in }} \\
\text { of our study }\end{array}$ & $\begin{array}{c}\text { Efficiency } \\
\mathbf{P}_{\text {op }} / \mathbf{P}_{\text {in }} \\
\text { Of searcher } \\
\text { study[20] }\end{array}$ \\
\hline 1000 & 99.44 & 98.50 \\
800 & 98.9 & 99.36 \\
600 & 99.53 & 99.47 \\
\hline
\end{tabular}


Table 6. (b) Fuzzy MPPT efficiency at specific irradiation multi-temperature for two studies

\begin{tabular}{ccc}
\hline $\begin{array}{c}\text { Temperature } \\
\mathbf{C}^{\circ} \text { at } \\
\text { irradiation } \\
(\mathbf{1 0 0 0}) \mathbf{w} / / \mathbf{m} 2\end{array}$ & $\begin{array}{c}\text { Efficiency } \\
\mathbf{P}_{\text {op }} / \mathbf{P}_{\text {in }} \\
\text { Of our study }\end{array}$ & $\begin{array}{c}\text { Efficiency } \\
\mathbf{P}_{\text {op }} / \mathbf{P}_{\text {in }} \\
\text { Of searcher } \\
\text { study [20] }\end{array}$ \\
\hline 20 & 99.4 & 99.45 \\
30 & 99.39 & 99.30 \\
35 & 99.23 & 99.22 \\
\hline
\end{tabular}

Through the results of table5 (a) and(b), it is clear that the efficiency of the system for our study is better than the previous study because we used Seven subsets for (E), (CE), and (D) output (the previous study [20]used five).

\section{Conclusion}

The main aim of this paper is to design an efficient algorithm for the solar energy system because the current-voltage curve has non-linear characteristics and is affected by weather conditions instantaneously. This was achieved by using the fuzzy Mamdani logic controller technique FMLC. The FMLC is adjusted the duty cycle PWM of boost converter switch device, with an efficiency of up to $99 \%$ and stable output power and for different atmosphere conditions applied on the PV panel array. The data is carried out by using a simulation MATLAB Simulink tool. The proposed design shows better performance than the most famous technique of MPPT (P\&O) for the same system specification in terms of efficiency and thus powers output. However, the efficiency of FMLC increases when an increasing subset of crisp leading to optimum accuracy for this topology.

\section{Conflict of Interest}

The authors declare that there are no conflicts of interest regarding the publication of this manuscript.

\section{References}

1. L. Piegari and R. Rizzo, "Adaptive perturb and observe algorithm for photovoltaic maximum power point tracking," IET Renewable Power Generation, vol. 4, no. 4, pp. 317-328, Jul. 2010, doi: 10.1049/ietrpg.2009.0006.

2. N. Femia, G. Petrone, G. Spagnuolo and M. Vitelli, "Optimizing sampling rate of $P \& O$ MPPT technique," 2004 IEEE 35th Annual Power Electronics Specialists Conference (IEEE Cat. No.04CH37551), 2004, pp. 1945-1949 Vol.3, doi: 10.1109/PESC.2004.1355415.Desai， C.S. (2007). Unified DSC constitutive model for pavement materials with numerical implementation. International Journal of Geomechanics, Vol. 7, No. 2, pp. 83-101.

3. Chihchiang Hua, Jongrong Lin and Chihming Shen, "Implementation of a DSP-controlled photovoltaic system with peak power tracking," in IEEE Transactions on Industrial Electronics, vol. 45, no. 1, pp. 99-107, Feb. 1998, doi: 10.1109/41.661310.

4. M. G. Villalva, J. R. Gazoli, and E. R. Filho, "Comprehensive approach to modeling and simulation of photovoltaic arrays," IEEE Transactions on Power Electronics, vol. 24, no. 5, pp. 1198-1208, 2009, doi: 10.1109/TPEL.2009.2013862

5. MOTAHHIR, Saad, et al. " Shading effect to energy withdrawn from the photovoltaic panel and implementation of DMPPT using $C$ language". International review of automatic control, 2016, 9.2: 88-94. doi: 10.15866/ireaco.v9i2.8850

6. Y. Yang and F. Blaabjerg, "Overview of Single-phaseGrid-connected Photovoltaic Systems," Electric Power Components and Systems, vol. 43, no. 12, pp. 1352-1363, Jul. 2015, doi: 10.1080/15325008.2015.1031296. 
7. Sharma, Pradeep and Brahmaiah, V. Siva and Kumar, Mantosh, "Iot Integrated System and Efficient Utilization of Solar PV Power Energy". (February 21, 2020). Available at SSRN: https://ssrn.com/abstract $=3554936 \quad$ or http://dx.doi.org/10.2139/ssrn.3554936

8. B. M. Hasaneen and A. A. Elbaset Mohammed, "Design and simulation of DC/DC boost converter," 2008 12th International Middle-East Power System Conference, 2008, pp. 335-340, doi: 10.1109/MEPCON.2008.4562340.

9. Zhicong Chen, Lijun Wu, Shuying Cheng, Peijie Lin, Yue Wu, Wencheng Lin, "Intelligent fault diagnosis of photovoltaic arrays based on optimized kernel extreme learning machine and I-V characteristics". Applied Energy,Volume 204,2017,Pages 912-931,ISSN 0306-2619, doi:10.1016/j.apenergy.2017.05.034.

10. Unal Yilmaz, Ali Kircay, "Selim Borekci,PV system fuzzy logic MPPT method and PI control as a charge controller",Renewable and Sustainable Energy Reviews,Volume 81, Part 1,2018,Pages 994-1001,ISSN 1364-0321, doi:10.1016/j.rser.2017.08.048.

11. H. Mahamudul, M. Saad, and M. Ibrahim Henk, "Photovoltaic system modeling with fuzzy logic based maximum power point tracking algorithm," International Journal of Photoenergy, vol. 2013. 2013, doi: $10.1155 / 2013 / 762946$.

12. Hafedh Abid, Ahmed Toumi, Mohamed Chaabane, "MPPT Algorithm for Photovoltaic Panel Based on Augmented Takagi-Sugeno Fuzzy Model", International Scholarly Research Notices, vol. 2014, Article ID 253146, 10 pages, 2014. Doi: $10.1155 / 2014 / 253146$.

13. HUA, Chihchiang; SHEN, Chihming. "Study of maximum power tracking techniques and control of DC/DC converters for photovoltaic power system". In: PESC 98 Record. 29th Annual IEEE Power Electronics Specialists Conference (Cat. No. 98CH36196). IEEE, 1998. p. 8693.doi:10.1109/pesc. 1998.701883.

14. Annual IEEE Computer Conference, Electric Power Quality and Supply Reliability Conference 9 2014.06.11-13 Rakvere, PQ 9 2014.06.11-13 Rakvere, and International Electric Power Quality and Supply Reliability Conference 9 2014.06.11-13 Rakvere, 2014 Electric Power Quality and Supply Reliability Conference (PQ) 11-13 June 2014, Rakvere,

Estonia.doi:/10.1109/pq32531.2014.

15. Ahmed M. Othman, Mahdi M.M. El-arini, Ahmed Ghitas \& Ahmed Fathy (2012) "Realworld maximum power point tracking simulation of PV system based on Fuzzy Logic control", NRIAG Journal of Astronomy and Geophysics, 1:2, 186-194, doi: 10.1016/j.nrjag.2012.12.016.

16. M. A. Eltawil and Z. Zhao, "MPPT techniques for photovoltaic applications" Renewable and Sustainable Energy Reviews, vol. 25. Elsevier Ltd, pp. 793813, 2013, doi: 10.1016/j.rser.2013.05.022.

17. T. L. Kottas, Y. S. Boutalis, and A. D. Karlis, "New maximum power point tracker for $P V$ arrays using fuzzy controller in close cooperation with fuzzy cognitive networks," IEEE Transactions on Energy Conversion, vol. 21, no. 3, pp. 793-803, Sep. 2006, doi: 10.1109/TEC.2006.875430.

18. MAMDANI, Ebrahim H.; ASSILIAN, Sedrak. " An experiment in linguistic synthesis with a fuzzy logic controller ". International journal of man-machine studies, 1975, 7.1: 1-13.doi:10.1016/s00207373(75)80002-2.

19. Aslam Mohamed, "P\&O," MATLAB Central File Exchange. Retrieved February 1, 2021., 2021, Accessed: Feb. 01, 2021. 
[Online]. Available: https://www.mathworks.com/matlabcentral/ fileexchange/74705-solar-pv-mppt-usingboost-converter-and-p-o.

20. M. Kamran, M. Mudassar, M. R. Fazal, M. U. Asghar, M. Bilal, and R. Asghar, "Implementation of improved Perturb \& Observe MPPT technique with confined search space for standalone photovoltaic system," Journal of King Saud University Engineering Sciences, vol. 32, no. 7, pp. 432-441, Nov. 2020, doi: 10.1016/j.jksues.2018.04.006.

21. M. Z. Abdullah, I. Sudiharto, and R. P. Eviningsih, "Photovoltaic System MPPT using Fuzzy Logic Controller," in Proceedings - 2020 International Seminar on Application for Technology of Information and Communication: IT Challenges for Sustainability, Scalability, and Security in the Age of Digital Disruption, iSemantic 2020, Sep. 2020, pp. 378-383, doi: 10.1109/iSemantic50169.2020.9234200. 